\title{
Bertrand de Jouvenel on Power, Authority, and Trust
}

\author{
Daniel Rosenberg \\ PhD Candidate, Department of Political Sciences, Hebrew University of Jerusalem \\ Address: Hagalil 135 Street, Haifa, Israel 32683 \\ E-mail: daniel.rosenberg@mail.huji.ac.il
}

\begin{abstract}
The paper will examine Bertrand de Jouvenel's account of political authority and its relation with the question of trust. Jouvenel's work offers a provocative and unique account of political authority, viewing it first and foremost as a type of instituting regular and reliable social relations between different members of a social community. As part of his thesis, Jouvenel distinguishes between two major types of political authority, which are referred to in the course of his writings as "power" and "authority." While power, generally speaking, proceeds through the containment of individual agency in given fields, primarily through an appeal to personal interests or direct coercion, authority is manifested primarily in a charismatic or informal type of leadership influencing the agent's behavior at a more implicit level. The distinction between power and authority, as Jouvenel emphasizes, implies a double conception of trust as an ethical and epistemic principle. While power provides the necessary regularity by means of mediated information which is normally embedded in certain bureaucratic organization, authority provides a more immediate type of regularity by instituting "hubs" of social regularity, especially through the quality of personal character. The relation between the two types of political authority can be seen as involving a type of equilibrium. While power deals with reducing the externalities and risk that are encompassed in human interaction and allows for basic subsistence, authority allows for a wider array of human choices, while at the same time keeping power from overwhelming the social fabric. The main focus of Jouvenel's political theory is the conservation of the elusive and implicit social tie which allows authority to play its unique role, while keeping it distinct from the more mediated forms of political power at the same time.
\end{abstract}

Keywords: power, authority, trust, knowledge, charisma, individualism

\section{Introduction}

Bertrand de Jouvenel's political and social theory centers on the relation between trust and authority, particularly in the context of a modern pluralistic society. ${ }^{1}$ Jouvenel's main

\footnotetext{
(c) Daniel Rosenberg, 2016

(C) Centre for Fundamental Sociology, 2016

DOI: $10.17323 / 1728-192 \mathrm{X}-2016-4-130-145$

1. Jouvenel's work has been the subject of complex academic reception. As Robert Grady helpfully summarizes, "the political thought of Bertrand de Jouvenel may seem quaint and out of place on first reading. His writings are often greeted with cordial befuddlement: the cordiality due a wise and insightful author; the befuddlement given an obscure writer. Indeed, he is an obscure political theorist. A highly regarded contemporary more highly regarded in Europe than America he is not obscure because unknown. Nor is he obscure because obscurantist, although this is the gist of more than one assessment. He is obscure, rather, because the sum of his major works appears to be diversified, disjointed, and to lack a coherent thread tying it together. One sees both romantic and realist, idealist and scientist, critic of income redistribution and advocate of planning, conservative and liberal" (Grady, 1981: 365). This difficulty, which arises in part on account of Jouvenel's elusive vocabulary, should not be taken as a mere inconsistency.
} 
impetus is to rescue the idea of authority from two dominant interpretative tendencies, one which is to trivialize authority and to regard it as a mere functional appendage and the other, the tendency to regard it as a completely independent and constitutive, almost transcendent political form. In lieu of opting towards one or another approach, Jouvenel introduces a different conception of authority which emphasizes the way in which authority operates as a propagator of trust in society. Authority is not a purely prohibitive instance, as it has a productive quality. Authority produces a certain type of social regularity which arises from a unique individual position, and cannot be reduced to a mere service or commodity. As such, this authority acts as a unique type of vehicle which is indispensable for the formation of trust across various social spheres.

I begin my paper by clarifying the epistemological and conceptual fundaments of Jouvenel's thesis which centers on the use of knowledge in society, and its relation with various mechanisms of social regularity. I continue by addressing the different types of power which Jouvenel identifies in society, with an emphasis on the way in which they generate, or hinder the growth of social trust, a process which is accomplished through the creation of voluntary groups. I then conclude the paper by pointing out certain institutional and political considerations which emerge from my discussion on Jouvenel's political theory, and the way these considerations correspond to the overarching theme of trust.

\section{Knowledge and Freedom}

Jouvenel begins from an epistemically-defined assumption which views knowledge as the cornerstone of all social institutions and processes. For Jouvenel, it would be accurate to say that the individual is first and foremost a data-processing animal. All social action consists of influencing the thoughts, feelings, and primarily, the behavior of other people. Therefore, it requires a special type of knowledge, that of the human persona, which is usually implicit in human relations and does not come to the fore in any express way: "The regular and foreseeable behavior of . . . others and the possibility of anticipating their reactions with the smallest margin of error are the pillars on which every individual calculation rests" (Jouvenel, 1963b: 115).

For Jouvenel, there is a strong affinity between knowing and doing. Before one does anything, he or she must have a clear idea of the results and consequences of their action:

There is nothing of which we are more aware, whatever philosophers may say, than our ability to bring about certain situations by our choice served by our efforts. I can, if I want to, raise this glass to my lips. When I raise it, I am aware that I am "causing" its new position. But, to speak more accurately, the very notion of "cause," common to all men, is a product of such experiences. From my earliest childhood, I have found that I can change something, however little, in my environment, by my action, and from this microcosmic experience of a relation between my effort and this change arises the general idea of "cause and effect." (Jouvenel, 1963a: 6) 
The concept of freedom naturally calls into mind its opposite, that of coercion. Jouvenel has a very un-typical view of the notion of coercion. Rather than being merely a form of violent intrusion, coercion implies the limiting of one's ability of forecast by altering the predictable actions of other social agents. Understood in such a way, it is not entirely clear individuals are in fact capable of coercing each other in the direct sense, since the others' actions are normally taken into account in our "probability matrix" of social life. Where coercion does appear is in the emergence of an inhospitable environment. Jouvenel alludes to Kafka and Dostoyevsky and those authors' depictions of the loneliness and anxiety brought about in those individuals permanently residing in "Otherdom" (ibid.: $61)$.

It is then clear that not all knowledge advances one's freedom to the same degree; this knowledge needs to be valid, relevant, and applicable. As part of Jouvenel's epistemology, he does not consider all knowledge about society to be encompassed in scientific formulae. ${ }^{2}$ For Jouvenel, all of our knowledge on society and social processes arises from concrete experience. ${ }^{3}$ Accordingly, he criticizes the attempt to circumscribe the full extent of social relations by means of normative or scientific theory. Jouvenel also emphasizes the way in which the goals of different agents is what complicates our ability to predict human behavior, as opposed to the causes of their actions (the $u$ t as opposed to the quia). It is because humans have "projects" that they are able to carry out free actions, or projects that are themselves impossible to predict according to any objective factors (Jouvenel, 1967: 26-30).

Since absolute and complete prognostication is never truly possible, the abilities required to plan one's actions is knowledge of the existing state of affairs in society, in particular, the relatively static or regular factors, and to distinguish those from the more dynamic and less predictable social elements. Jouvenel calls the former "datum" and the latter "casuels" (roughly, French for "casual" as in "happening by chance"). These two types of variables are used to construct a "map of the present," according to which the individual can navigate society (ibid.: $37-39$ ).

Jouvenel generally considers the two approaches as two social arrangements, one that is rooted in "order," and one that is rooted in "organization" (Jouvenel, 1999d: 65-76). While order emerged from a process of habitual usage through an extended period of time ("a process of action"), organization is rooted in conformity with an external principle ("process of thought"). While the former emerges mostly unintentionally from the

2. Jouvenel, who was a professional economist, dedicated some of his efforts to criticize some of the dominant paradigms of neoclassical economic science. Among his translated works on the subject are Efficiency and Amenity (1999a), The Political Economy of Gratuity (1999b), and his seminal essay The Ethics of Redistribution (1990).

3. Jouvenel's political theory was developed almost in tandem with that of Friedrich Hayek, another famous continental liberal. It is in Jouvenel's idea of social knowledge in particular that one can sense strong Hayekian overtones; compare it with Hayek's famous formulation which hails authentic social knowledge as the result of a "process of experimental interaction of widely dispersed, different and even conflicting beliefs of millions of communicating individuals" (Hayek, 1989: 80). Michael Polanyi's concept of "personal (or tacit) knowledge" is also a relevant point of comparison (Polanyi, 1962). 
mere cumulative usage on the part of different persons, the latter is always a result of an intentional act. It would be wrong to assume, however, that the former is devoid of reason; order represents a type of rationality that characterizes the actors themselves, while organization represents the rationality of an external (usually third party) evaluation. Jouvenel brings up the example of an owner of a library whose daughter rearranges his library alphabetically while he is on vacation; the old, useful order was destroyed in favor of a more or less abstract principle. What Jouvenel describes is, in fact, two types of knowledge; one that directs the thought of the "organizer," and one that is implicit in the process of the action itself.

Note that Jouvenel does not mean to say that two types of societies exist, but two types of social attitudes. One of these attitudes is more sensitive to nuances and the tacit forms of social minutiae, while the other deduces social rules from abstract ideas. While both approaches are valid in the sense of internal compatibility, it is clear that the latter approach misses something of the social experience; it may not really be outright absurd, but rather lacking in a very important sense of acknowledging the subjective meaning of social behavior. The individuals who took the task of organization upon themselves do not experience the real order of things or grasp its various advantages or shortcomings for its members. Rather, they are interested mainly in its appeal to their subjective taste, to their "feeling of orderliness" (ibid.: 66). The social engineers are thus unable to envision the full consequences of the order they propose, since they do not take an actual part in it. The distinction between the two types of knowledge can be seen in the following paragraph, wherein Jouvenel uses theological language to demonstrate the two approaches to knowledge (Jouvenel, 1945: 359):

When the intelligence, unsupported by either study or revelation, applies itself to its essential objective, the knowledge of God, it forms by a natural process two antithetical connections. One is that of a miraculous Providence, which is reached and set in motion by prayers for particular objects and then intervenes to disturb for the benefit of its invoker the natural course of things. And the other is that of a supreme Wisdom, which has subjected everything to laws of a majestic regularity and then leaves them to operate unchecked.

These two theological forms correspond to the two different epistemic forms: one operates via discovery, or "revelation," and the other operates via the setting of abstract rules. Between the two, it is the former that actually achieves positive knowledge, while the latter merely reorganizes or reinterprets knowledge according to some principle. In the realm of ethics or human behavior in general, the former type corresponds to "unceasing vigilance," or a perpetual awareness to the change and mutation in social rules (ibid.: 360), while the latter indicates a process of abstract reflection, which may be arrived with only a minimal examination of the real world.

The conceptual distinction introduced by Jouvenel thus taps into an important intellectual tradition, one which emphasizes the primacy of practical over theoretical knowledge. Practical knowledge quite paradoxically enjoys this primacy because it allows for 
more regularity in concrete social matters, unlike abstract knowledge that is grounded in the concrete and consistent experience of the world. This is what Hayek means when he invokes the "knowledge of some regularities in society" which "create[s] a preferences for those kinds of conduct which produce a confident expectation of certain consequences, and an aversion to doing something unfamiliar and fear when it has been done" (Hayek, 1978: 79).

When translated into the language of social behavior, these types indicate two different ways of acquiring social knowledge, either theoretically or practically. The theoretical one is fairly simple. It is concerned with the deciphering of social processes by means of reflection, that is, rational and conscious assessment. The other, the "revelatory" type of knowledge is trickier, implying a direct experience of social life. It is knowledge that is acquired through the imitation and gradual adaptation to social norms and institutions, usually by the simple fact of taking an active (or passive) part in a given social arrangement. It would be wrong, however, to assume that this type of knowledge is completely devoid of mediation: it is mediated through selected social agents who we imitate. This very distinction is what lies at the heart of Jouvenel's idea of authority.

\section{Power and Authority}

Jouvenel calls the cornerstone of every form of social mediation the "imperative." An imperative is essentially a plea for action, for acknowledge, for expenditure of effort, and so on. It can take the form of a political appeal, an advertisement, or even a cry for help (Jouvenel, 1963a: 73). In accordance with his classification of social knowledge, Jouvenel identifies two different modes of transmitting information in society via the "imperatives" of power and authority. The first type, power (at times capitalized in Jouvenel's corpus as "Power") represents the "organizational" type of knowledge-power by the continuous rearrangement of social relations on the basis of some external paradigm. It is essentially a notion of power as a deterministic force which belongs to nature and to which individuals belong to merely as moving parts. ${ }^{4}$ The second type, defined as "authority," does not involve correspondence with some external pattern, but is rather the imitation of existing social patterns. As such, authority is manifest in other human beings as living agents, in certain institutions, symbols and groups, and primarily in individuals. Between the two, the first one is highly abstract and is addressable only in metaphoric language, or through mechanistic or organic analogies, while the second is direct, real, and highly concrete. In its logic, the first type unifies different phenomena, which it regards as parts of a long causal chain, while the second emphasize the distinctiveness of different social agents and their separate natures.

A good way of understanding the distinction between the two forms of power is by addressing their different explanatory structures. Power is justified by a concrete inter-

4. Like many French thinkers, Jouvenel uses a notion of power that travels a long way back in European thought. The notion of power as a pure structure of functionality that is at odds with agency goes back to Émile Durkheim, and perhaps even to Joseph de Maistre. 
est, usually (although not necessarily) formulated in individualistic terms; power exists because one wants to do something which he or she is unable to achieve through an individual effort. It is an accessory or an instrument; think, for example, about Hobbes's homo artificialis. Authority, on the other hand, is gratuitous; it has no end other than itself. It cannot be propelled by private interest since it cannot be founded by the receiving agent, who encounters it already-formed. Accordingly, it also cannot be established by formal agreement between members, since this agreement implies an anterior function that needs to be served. Jouvenel explains the idea of authority in his passage (Jouvenel, 1963: 92):

While the term [authority] has a great variety of meanings, the simplest is that which is closely linked with the word "authorship": a statement is authoritative by virtue of the credit afforded to its particular author. Should I state that there can be a speed no greater than that of light, I should provoke laughter; but should Professor Heisenberg say so, his authority would command world-wide attention. ${ }^{5}$

These two types can be seen as expressed in different types of human activities. The first type lies at the heart of common material and economic activities, of labor, reproduction, and certain types of warfare. The individual encounters it when he or she is complying with an external command for fear of physical violence, or when he or she is entering into formal contracts or employment in a business firm. It is, however, in the relation of civic obedience that power exists in its most undiluted form. The state, whether it is socialist, liberal, oligarchic, or democratic, exists only for some external end, be it the defense of rights, the redistribution of property, the serving of some group interest, and so on. It is nothing but a social instrument for the "expression of society, a mere conduit, by means of which society rules itself" (Jouvenel, 1945: 21).

Authority, on the contrary, is not established by means of any general institution, but by personal agency. It remains embedded in a certain time and place, and most of all, in the individual in whom authority is vested. Jouvenel defines the auctor as "the man whose advice is followed, to whom the actions of others must in reality be tracked back; he instigates, he promotes" (Jouvenel, 1963b: 30). When authority is founded, there is nothing to guarantee its success other than the personality and charisma of its founder. Unlike power that relies on professional expertise or function such as an economic or

5. This account of authority might sound familiar to readers of Hans-George Gadamer, who, in the second volume of Truth and Method, describes authority in the following way: "[I]t is primarily persons that have authority; but the authority of persons is ultimately based on the subjection and abdication of reason but on an act of acknowledgement and knowledge-the knowledge, namely, that the other is superior to oneself in judgment and insight and that for this reason his judgment takes precedence-i.e., it has priority over one's own. This is connected with the fact that authority cannot be bestowed but is earned, and must be earned if someone is to lay claim to it. It rests on the acknowledgement and hence on an act of reason itself which, aware of its own limitations, trusts to the better insight of others" (Gadamer, 2004: 281). While a more extensive comparison might be in order, it would suffice here to remind that Jouvenel regards authority as facilitating a particular type of knowledge, namely, one about concrete social conditions, while Gadamer is addressing knowledge in general. As such, Gadamer's account can be seen as more general and formal, while Jouvenel's is more functional and specific. 
judicial one, there is no prior institutionalized set of rules which determine the obligation of a person towards authority. Accordingly, there is also no easy possibility to alienate or transfer authority from the auctor to a third party.

Since the holder of authority is not designated by another instance, obligations towards him or her similarly cannot also be derived from an existing principle. We have already seen that, for Jouvenel, obedience is not that mark of authority, but of power. The individual who commits his or herself to authority does it not out of utilitarian or existential grounds, but out of internal accord: authority begins for an imperative that is grounded in "the prestige, personal or institutional, of the man speaking-a prestige linked to the guarantee furnished by the exalted character recognized in him" (ibid.: 75 ). Authority, then, does not begin at the moment the command (or "imperative") is given; rather, it begins the moment a holder of authority is recognized by its would-be subjects. The initiator of this process is not the agent of authority but actually its recipient, who, by his or her own personal choices, "delegates" authority upon the other agent of his or her choice (Jouvenel, 1963a: 92). ${ }^{7}$

\section{Authority as Personal Character}

As we have just seen, what lies in the center of the notion of authority is the individual's ability - and necessity - to adapt to his or her environment, a process requiring the mediation of other agents. The mechanism described here, in fact, is one of selection and imitation. The subject of authority is exposed to a myriad of appeals on the part of other individuals, or "suggestions" in Jouvenel's terminology (ibid.: 85). The choice of whether to accept or decline those suggestions lies squarely with their addressee; while some choices might be easier to make (Professor Heisenberg's scientific authority in the last example), other choices, namely those that pertain to social behavior and are completely devoid of objective content, are more difficult to make. The major question here lies in the "fitness" of the other agent to serve as an object of imitation, which would put him or her, by definition, in a position of authority. In contrast with forms of more theoretical knowledge, the fitness of the holder of authority lies rather squarely in his or her ability to reflect and to transmit social rules of behavior, a trait which Jouvenel associates with personal agency and character. ${ }^{8}$

6. Interestingly, Jouvenel notes that the imperative of authority might also be directed from a lower rank in the social hierarchy to a higher one in the form of an "imperative of supplication": he lists the examples of a cry for help, an appeal of debtor to his creditor, and even that of a prayer (ibid.: 73-74).

7. There is a strong similarity between Jouvenel's concept of obedience as establishing, and in a certain way, preceding authority, and Weber's notion of selection defined as a "struggle ... for advantages . . . but without a meaningful mutual orientation in terms of conflict" (Weber, 1963: 38). The main practical distinction, here and elsewhere, lies in Jouvenel's latent teleology with respect to his concept of authority. I wish to thank the anonymous reviewer of my manuscript for bringing this and other references to my attention.

8. A case can be made for comparing Jouvenel's idea of authority with the Weberian notion of charismatic leadership. While both thinkers' notions are descriptively similar, Jouvenel uses the term to designate behavioral modes rather than institutional forms; as such, his system allows for more flexibility and even hybrid authority types. Jouvenel's idea of authority is also different in the way in which it contains a weak but prominent teleological aspect, in the way he addresses authority and power as knowledge-propagating instances. 
It is no coincidence, Jouvenel tells us, that authority, foundation (auctoritas), and authorship are semantically related in denoting personal responsibility that is essentially irreducible and inalienable (ibid.: 20-22). Authoritative persons are those whose actions and behavior are determined by their own autonomous volitions, and not by the pressure of social forces. Jouvenel associates this type of behavior with the assuming of responsibilities. For example, when discussing authority in the ancient world which lies with the Roman freeman, Jouvenel emphasizes the patrician sense of voluntary obligation. The ethos of responsibility is both what creates as well as limits the personal freedom of the member of the patriciate. The ability to take on obligations, in the concrete sense (that of monetary debt is one example), is what made the nobleman into a free agent, as encompassed in the saying "etiamsi coactus, attamen voluit" (even though compelled, he decided) (Jouvenel, 1945: 320).

In such a way, it may be said that what both creates charismatic authority and maintains it as a "hub" of social knowledge is one's character. Jouvenel defines this as follows: "a man's character is what reconciles his freedom with the predictability of his actions by others. A man who acts according to his character surely acts freely; but also his action can be foreseen by another party who knows his character" (Jouvenel, 1963a: 87). Acting according to character corresponds to acting upon one's autonomy, as opposed to acting under the influence of circumstances or passions, as has been marked by philosophers throughout the ages. ${ }^{9}$ Character is not only used here as an ethical quality, but also as a political and an epistemic one. Since the person of character is autonomous, he or she does not fall into the deterministic trap of power, and is thus able to reflect something more than just a myriad of abstract social forces.

This notion of personal authority as character has a slightly more latent second aspect, which pertains to the adaptation of behavioral patterns through imitation. As noted by certain theoreticians of spontaneous order, ${ }^{10}$ there is actually very little possibility of changing one's behavior via explicit decrees on the part of other social agents. Jouvenel introduces a way in which individuals alter and successfully adapt their behavior with the social environment, which is done via consistent and regular personified input (the fact that Jouvenel himself frames this process in somewhat conscious terms is, I think, typical for his rhetoric but does not change the core of the argument). In other words, it is compatible with our understanding of ourselves as free and autonomous agents precisely because compliance with personal authority relies on seemingly "irrational" motives.

What this idea calls into question, of course, is the very possibility of a rational or "rationalized" authority. Under this prism, authority can never truly be "rationalized" in the strict sense of arising from an existing set of explicit formulae. The holder of rational-

9. See, for example, J. S. Mill: "A person whose desires and impulses are his own-are the expression of his own nature, as it has been developed and modified by his own culture-is said to have a character. One whose desires and impulses are not his own, has no character, no more than a steam-engine has a character" (On Liberty, III.5).

10. As put most eloquently by Friedrich Hayek: "[The formation] of superindividual patterns or systems of cooperation required individuals to change their 'natural' or 'instinctual' responses to others, something strongly resisted" (Hayek, 1989: 13). 
legal authority is thus merely an operative or an executioner, never a leader, since his or her aims and behavior cannot be traced to their own volition or responsibility. Every authority is, in the final instance, a moral authority.

\section{Institutionalization of Power and Authority}

The one institution in which power and authority are combined is the household. As a child, the individual encounters the two forms of social power: power in the form of the strong and capable adult with the ability to act, and power as the promotion and defense of a certain ethical way of life: "Ask a child to describe 'the ways of the home': if he can be induced to the intellectual feat implied, you will find that the result looks somewhat like the 'Twelve Tables' of the Roman law. The child will have picked out the way some things are done 'when they are done right"' (Jouvenel, 1963a: 51).

The household is an exceptional case, since in the household, the individual's dependence on others does not lead to those others' objectification; the relation between the parents and the child is both a "downward flow of services and goods" and that of ethical tutelage (ibid.: 47). However this is a unique social form that is essentially irreproducible. The social world is essentially divided between agencies of power and agencies of authority, which differ fundamentally in their internal structure as well as in their social function.

We have already seen that the structures Jouvenel attributes to the two types of social power correspond to their different functions. Power is the guarantor of capacity, in the sense of greater physical security or material advantage, while authority provides one with a familiarity with his social environment. The two types are also institutionalized in different and opposite ways. The former is perpetuated through different bureaucratic agencies and through state power, while the latter is centered on the individual "instigator" and his or her agency, which is in turn achieved through that instigator's own character, or charisma.

In political science literature, charismatic leadership is often regarded as a kind of momentary "flash in the pan," a sudden disruption that is unstable and even revolutionary. This is quite the opposite from how Jouvenel perceives it. Not only is charisma a more consistent element in society in the wider sense, but in rationalized authority, or power, it is the promoter and main beneficiary of instability. This effectively means that the main drive, or "efficient cause" of authority, cannot be transferred or delegated to an established bureaucratic body. Jouvenel describes the process in which authority is consolidated into an institutional form as contradictory and dangerous with respect to the essence of authority. Jouvenel illustrates this point by saying that "authority is institutionalized; artifice prolongs the effects of nature, just as a weak voice is strengthened by such helpful devices as the rostrum and the loud speaker ... when majesty goes out, the police comes in" (Jouvenel, 1963b: 72-73).

This does not, however, preclude the possibility of the institutionalization of personal authority through less formal means. What authority creates is what Jouvenel calls a 
"team," or a "group of action." A group is not an egalitarian structure. It operates both on a horizontal axis, a relation of egalitarian peerage between the members of the group, and a vertical axis that operates between the members and the leader of the group. While groups of action may very well have an external goal, as its name suggests, this goal is mediated by its internal hierarchical division of labor. Every formation "gets into gear through the initiative of a single man, who sows among others the seed of his purpose; some of them, in whom it rises, turn into a small group of apostles for the scheme, and these form the nucleus that preaches and recruits" (ibid.: 28).

What Jouvenel describes, then, is a process of imitation or "contagion" through which knowledge and accordingly forms of behavior are disseminated. Since the group is, after all, a concrete institution, it means that norms are never entirely self-sustaining but rather require the continuous affirmation within the group's structure. What this means is that forms of behavior can never truly be generalized since such a generalization would entail losing their source and thus, their legitimacy. It also means that Jouvenel's model is not evolutionary after all, but functionalist. There is thus a very strict limit on the institutionalization of authority, whose extent is more or less equal to the ability of the individual to communicate naturally, without the mediation of third parties or institutionalized agencies. This is what Jouvenel means when he remarks that "the more distant that an authority is, the more it needs a halo, or, if no halo is available, the more policemen are needed" (ibid.: 77).

It is then the vertical structure which relies on personal communication that prevents the association from becoming a merely utilitarian combination of interests. Jouvenel presents the relation of the group members with the holder of authority as essentially an ethical one, which implies a sense of common values and participation of a common lifestyle. Jouvenel formulates this appeal as: "Join up behind my white cockade' is imperative in form, and this imperative is explained by what follows: 'you will find it always following the path of honour'. Here there is also something implied: assuming that men such as you are, or want to be, are determined to take the path of honour, and that I for my part am embarked on it, then my cockade is the sign that teaches you the path which you should logically follow"' (ibid.: 74).

What the group promotes, then, is not necessarily an external cause as much as an internal, immanent cause which is inherent in its own existence and its manner of operation. Individuals who take part in such a group do not necessarily feel that they are protected or that their interests are served in the strict or immediate sense. Rather, they feel a kind of "epistemic security", a sense of reliability and predictability that Jouvenel defines as a way of life, or "common bonds, which assure that they are naturally drawn together ... a natural community which, in turn, inspires individual conduct" (1999a: 112). This, instead of any express interest, is the "efficient cause" of the group.

It is possible to understand this double role if we keep in mind that the functional element of authority is always the dissemination and sustenance of social knowledge. Social knowledge within a group is manifest as forms of trust and mutual reliability, which in themselves begets new forms of relations, and a closer and more intense dynamic among 
the members of the group (Jouvenel, 1963b: 125-126). It is thus no coincidence that Jouvenel describes the initial experience which rescues the individual from a state of anomy in a new environment not as tutoring or instruction, but friendship. Only a non-formal or established relation allows for a veritable transmission of social knowledge: "The formation of friendships is like the surging-up of hospitable islands in the open sea of Otherdom" (Jouvenel, 1963a: 65).

This concept of a group is opposed to the other type of institutionalization which Jouvenel describes, that of power. The institutionalization of power can be described as a response to a state of emergency which breaks out once all other authorities have failed. Let us remember that power does not introduce us to knowledge of the world, but rather reinterprets existing knowledge according to some external and alien principle. This form of knowledge is also not our first choice, but actually appears in times of social indeterminacy or "anomie." Despite its attempt to appear as a regulative and orderly apparatus and its tendency to see the social world in terms of mechanical constructs, it cannot but constantly affect changes, re-organize and revolutionize ways of life (Jouvenel, 1945: 160-162).

As such, power does not disseminate knowledge throughout society but reshapes, reinterprets, and centralizes such knowledge. In contrast with authority whose zone of jurisdiction is extremely limited, the range of operation of power is essentially universal. It creates new centers of control of knowledge by promoting itself as a mediating body between individuals and the general society. By increasing the individuals' ability to act, it has actually ceded the place of social certainty. As Jouvenel puts it (ibid.: 362):

It goes without saying that, thanks to the ingrained habit of legality, the interventions on which Power now embarks take on at first the form of laws But these [regulations of power] are but counterfeit laws, concerned only to provide for the situations of the moment, owning the imperious sway of current passions and requirements. Under the cloak of objective legislation, every subjective desire enjoys a saturnalia, as is shown both by the rapidity and the inconsistency with which these so-called laws multiply. Principle and certitude are things of the past; the desires of the moment become "your only lawgiver," no respecters these of the notions of moral good and natural necessity, which they confound with that of utility in its most transitory shape. ${ }^{11}$

Jouvenel then describes the process in which power grows in what can be labeled as an indefinite feedback loop, when centralization creates further anomie by disrupting spontaneous social processes, which in turn makes individuals turn to power as a means of maintaining a semblance of public order. Once power becomes imbedded as an ob-

11. This account corresponds with Axel Honneth's important description of the process in which the demands for individual self-realization paradoxically undermine the social trust which allows for individualization in the first place, a development in which "processes which once promised an increase of qualitative freedom are henceforth altered into an ideology of de-institutionalization, is the emergence in individuals of a number of symptoms of inner emptiness, of feeling oneself to be superfluous, and of absence of purpose" (Honneth, 1996: 467). 
jective and abstract need, it transforms into a self-sustaining mechanism. This is what Jouvenel calls a "social protectorate," or the grand mediator in society that embodies "The interests which uncertainty has frightened, the reason which disorder has offended, the feelings which misery has revolted, the imagination which the vision of future possibilities has inflamed" (ibid.: 353).

The institutionalization process of power, as opposed to that of authority, culminates in something very akin to the Foucaultian notion of power as a dispersed functional mechanism; this power is produced "from one moment to the next, at every point, or rather in every relation from one point to another" (Foucault, 1978: 93). Since knowledge disseminated by power essentially corresponds with individual capacity, it can be seen as a form of "subjection" in the Foucaultian sense of "constitution as subject in both senses of the word" (ibid.: 6o). Thus, it is precisely this ubiquitous and formless structure which makes power impossible to contain, as it lacks center and agency in any meaningful way. Since power tends to reduce social knowledge to matters of physical or material security, it means that it does not proceed by the establishment or the sustenance of norms, but only through arbitrary commands. Since it is by definition devoid of personal character, the institutional mechanism of power lacks the internal coherence needed to articulate itself in a consistent manner. Because power is merely a rationalized form of personal interest, and because interest itself is bound to the vacillations of society and human life, it is rendered in a constant and indeterminate state of flux.

The institutionalization of power is a process tinged with irony: it is the will to empower individuals and their ability to act which undermines intermediary powers and eventually take over ever-larger segments of the social edifice. At the opposite end, it is the recognition of the heteronomous nature of authority which actually institutes it as a separate instance and limits its zone of interference. What prevents the group from becoming a bureaucratic and opaque form of domination is the personal character of its founder which imbues the group with his or her authority. On the contrary, the structure of power is devoid of this authority-alterity, and by identifying itself in a non-mediated way with its subjects, encroaches heavily on their autonomy.

Since the dissemination of knowledge is always a process which involves interpersonal influence, it can never elude a significant degree of politicization. The question here pertains to the manner in which this politicization is accomplished, whether through a semi-institutionalized social authority that relies on personal responsibility, or through an impersonal and therefore ubiquitous mechanism. Paradoxically, the more the political aspect of social knowledge is manifested in the process of its production and dissemination, the more reliable it is, while the truth value of knowledge that is neutral, i.e., devoid of context and "speaker," is virtually null.

\section{Authority, Trust, and Politics}

As has been noted, Jouvenel's system can be seen as a reinterpretation of some of the classical concepts of political sociology (namely of a Weberian orientation), and their 
application in a specific political ethos. Thus, rather than a comprehensive sociological theory of authority, Jouvenel's explicit aim is to define a set of terms which could be used to protect an independent civil society from the incursions of a centralized state power, even if it is a democratic state. This problem has been analyzed most eloquently by Alexis de Tocqueville in the chapters of Democracy in America that speak about the cultural and psychological aspects of majority rule. The democratic citizens "all see each other at very close range; and, not noticing in any one of them the signs of incontestable greatness and superiority, they are constantly brought back to their own reason as the most visible and nearest source of truth" (Tocqueville, 2010: 700-701). The consequence of this reality, however, is not so much the empowerment of individuals as much as the destruction of any authentic trust between members of society; as Tocqueville puts it, "it is not only confidence in a particular man that is destroyed, but the taste to believe any man whatsoever on his word" (ibid.: 701).

Instead of relying upon any particular person as the center of confidence and trust, the democratic impetus promotes confidence through a different type of subjective common sense, what Tocqueville calls "the doctrine of the interest well understood." This doctrine replaces the imperatives of specific duties and obligations with a type of enlightened egoism (ibid.: 920). The process which Jouvenel proposes in order to explain the emergence of the social tie is remarkably close to that of Tocqueville. For Jouvenel, it is primarily through collective agency as part of a voluntary group that the individual receives his own personal value, as well as an internal sense of regularity and cohesiveness. However, unlike Tocqueville's system which underestimates the ability of a post-aristocratic society to introduce intermediate sources of authority, Jouvenel regards the emergence of those alternative centers of authority as part and parcel with the psychological and sociological dynamic of a decentralized polity via the action of prominent individuals.

In such a way, Jouvenel's model proposes both an explanatory and a normative idea of social dynamics and the solidification of social trust. While the constellation of social groups may seem like an overly static and homogenous arrangement, it actually allows for the diversity of ends, and as such represents a highly pluralistic-leaning idea of society. Indeed, Jouvenel considers the "inevitable diversity of men" as the cornerstone of every viable political model, and affirms that "life in society is altogether sweeter and richer when social positions of eminence can be reached from various starting places than when they reflect a single hierarchy" (Jouvenel, 1963b: 70).

What emerges here, in fact, is a model for the radical decentralization of political authority. Since the potential of authority to gather and unite individuals is almost inversely proportional to the coercive power it holds, it means the opportunities for the formation of independent groups and association are enormous in number. Since the variability of factors which influences the emergence of elements like charisma and personal character is almost infinite, and since the stakes of belonging to each association are rather trivial (associations usually do not require exclusive loyalty or significant material sacrifice on the part of their members), each individual can belong to a vast number of associations at any given moment. 
To a large degree, Jouvenel's project then appears as a response to the Tocquevillian challenge which seeks to reconstruct the social bond under conditions of modern individualism. Jouvenel's conception of authority as a trust-propagating instance allows for the construction of a relatively solid and consistent social bond without sacrificing crucial aspects of social pluralism. The idiosyncrasy of Jouvenel's theory is that by presenting authority as a spontaneous social institution, it stresses its ethical dimension and its "embeddedness" in normal human relations. As such, it allows us to see authority not as disruptive, but as conductive of trust.

Since Jouvenel's understanding of authority is centered largely, even almost purely, on the constructive relations between individuals, it also represents an amicable relation (albeit not a symmetrical one) which precludes coercion or any type of non-pacific intervention. As such, it also showcases the irreducible nature of trust, which cannot be constructed intentionally through any effort of social or political planning, and distinct from any type of deliberative model. While authority involves communicative action, it is not a form of communication formed by rational deliberation through the exchange of opinions but on a tacit and non-conscious type of consideration and approval (or rejection) of forms of cooperation. In such a way, it allows for a nuanced and complex understanding of the concept of social trust and its political ramifications.

Jouvenel's thesis thus can be said to introduce a vital element of politicization into social life. While authority is regarded as voluntary and decentralized (as opposed to bureaucratized Power), it is also extensive in a way institutionalized power is not. Since social life is never free from the influence of learning, emulation, and selection, all social relations are tinged with hierarchy to some degree. By stressing the indispensable nature of influence in society, Jouvenel vindicates politics and its immanent importance in virtually all forms of communication and cooperation.

By placing authority in the context of social trust and friendship as an instance which promotes rather than disrupts social relations, it is possible to re-insert the notion of authority into constructive political sociology. It might be possible to ask, for example, what types of authority are conducive to trust at the local and voluntary level, as opposed to the level of established politics. Alternatively, it would be possible to ask whether the notion of authority as propagator of trust can be institutionalized in a more rigid and systematic way than in the informal group-association. While Jouvenel is more or less silent on those points, this discussion can be teaching in light of the developments in early $21^{\text {st }}$ century political discourse, especially with the reintroduction of the notion of populism.

\section{References}

Anderson B. C. (2001) Bertrand de Jouvenel's Melancholy Liberalism. Public Interest, no 143 , pp. 87-104.

Foucault M. (1978) The History of Sexuality, Vol. 1: An Introduction, New York: Parthenon Books.

Gadamer H.-G. (2004) Truth and Method, London: Continuum. 
Grady R (1981) Bertrand de Jouvenel: Order, Legitimacy, and the Model of Rousseau, Interpretation, vol. 9, no 2-3, pp. 365-384.

Hayek F. (1978) New Studies in Philosophy, Politics, Economics and the History of Ideas, Chicago: University of Chicago Press.

Hayek F (1989) The Fatal Conceit: the Errors of Socialism, Chicago: University of Chicago Press.

Honneth A. (1996) Organized Self-Realization: Some Paradoxes of Individualization. European Journal of Social Theory, vol. 7, no 4, pp. 463-478.

Jouvenel B. (1945) On Power, Its Nature and the History of Its Growth, Boston: Beacon Press.

Jouvenel B. (1963a) The Pure Theory of Politics, New Haven: Yale University Press.

Jouvenel B. (1963b) Sovereignty: an Inquiry into the Political Good, Cambridge: Cambridge University Press.

Jouvenel B. (1967) The Art of Conjecture, London: Weidenfeld and Nicolson.

Jouvenel B. (1990) The Ethics of Redistribution, Indianapolis: Liberty Fund.

Jouvenel B. (1999a) A Better Life in an Affluent Society. Economics and the Good Life: Essays on Political Economy, New Brunswick: Transaction, pp. 97-118.

Jouvenel B. (1999b) Efficiency and Amenity. Economics and the Good Life: Essays on Political Economy, New Brunswick: Transaction, pp. 37-52.

Jouvenel B. (1999c) The Political Economy of Gratuity. Economics and the Good Life: Essays on Political Economy, New Brunswick: Transaction, pp. 53-64.

Jouvenel B. (1999d) Order versus Organization. Economics and the Good Life: Essays on Political Economy, New York: Transaction, pp. 65-75.

Mahoney D. (2005) Bertrand De Jouvenel: Conservative Liberal and Illusions of Modernity, Wilmington: Intercollegiate Studies Institute.

Polanyi M. (1962) Personal Knowledge: Towards a Post-Critical Philosophy, London: Routledge.

Tocqueville A. (2010) Democracy in America, Indianapolis: Liberty Fund.

Weber M. (1963) Economy and Society: An Outline of Interpretive Sociology, Berkley: University of California Press.

\title{
Бертран де Жувенель о власти, авторитете и доверии
}

\author{
Даниэль Розенберг \\ Аспирант департамента политических наук Еврейского университета в Иерусалиме \\ Адрес: Hagalil 135 Street, Haifa, Israel 32683 \\ E-mail: daniel.rosenberg@mail.huji.ac.il
}

В статье рассматривается понимание политического авторитета и его отношения с вопросом доверия, представленное в работах Бертрана де Жувенеля. Он предлагает провокационный 
и особенный взгляд на политический авторитет, рассматривая его в первую очередь как способ учреждения регулярных и надежных социальных отношений между различными участниками сообщества. В рамках своей аргументации Жувенель выделяет два типа политического авторитета, которые обозначаются как «власть» и «авторитет». В то время, как власть в целом возникает в результате сдерживания индивидуального действия в какой-либо области в основном посредством воззвания к личным интересам или прямого повеления, авторитет проявляется в первую очередь как харизматический или неформальный тип лидерства, влияющий на поведений человека косвенным образом. Различие между властью и авторитетом, как отмечает Жувенель, предполагает двойную концепцию доверия как этического и эпистемического принципа. Если власть обеспечивает необходимую регулярность при помощи опосредованной информации, которая обычно встроена в определенные бюрократические организации, то авторитет организует более косвенный тип регулярности, учреждая «узлы» социальной регулярности, в частности, через качества личного характера. Соотношение двух типов можно рассмотреть как предполагающее некое равновесие. Пока власть имеет дело с сокращением внешнего эффекта и рисков, которые предполагаются человеческим общением, и позволяет базовое существование, авторитет дает более широкий набор для человеческого выбора и в то же время удерживает власть от перегрузок социальной ткани. Основной фокус политической теории Жувенеля состоит в сохранении неуловимой и скрытой социальной связи, которая позволяет авторитету играть свою особенную роль и в то же время сохранять дистанцию от более косвенных форм политической власти.

Ключевые слова: власть, авторитет, доверие, знание, харизма, индивидуализм 